Discussion Paper No. 16-032

\title{
Extreme Weather and Risk Preference: Panel Evidence from Germany
}

Goytom Abraha Kahsay and Daniel Osberghaus

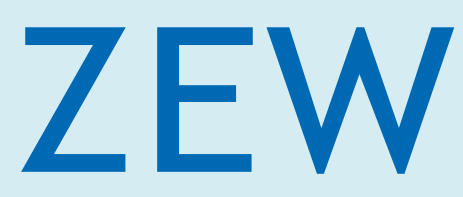

Zentrum für Europäische Wirtschaftsforschung $\mathrm{GmbH}$

Centre for European

Economic Research 
Discussion Paper No. 16-032

\section{Extreme Weather and Risk Preference: Panel Evidence from Germany}

Goytom Abraha Kahsay and Daniel Osberghaus

Download this ZEW Discussion Paper from our ftp server:

http://ftp.zew.de/pub/zew-docs/dp/dp16032.pdf

Die Discussion Papers dienen einer möglichst schnellen Verbreitung von neueren Forschungsarbeiten des ZEW. Die Beiträge liegen in alleiniger Verantwortung der Autoren und stellen nicht notwendigerweise die Meinung des ZEW dar.

Discussion Papers are intended to make results of ZEW research promptly available to other economists in order to encourage discussion and suggestions for revisions. The authors are solely responsible for the contents which do not necessarily represent the opinion of the ZEW. 


\title{
Extreme Weather and Risk Preference: Panel Evidence from Germany
}

\author{
Goytom Abraha Kahsay, and Daniel Osberghaus ${ }^{\mathrm{a}}$
}

April 2016

\begin{abstract}
Individual risk preference may change after experiencing external socio-economic or natural shocks. Theoretical predictions and empirical studies suggest that risk taking may increase or decrease after experiencing shocks. So far the empirical evidence is sparse, especially when it comes to developed countries. We contribute to this literature by investigating whether experiencing financial and health-related damage caused by storms affects risk preference of individuals in Germany. Using unique panel data, we find that households who report storm damage increased their risk taking. We do not find evidence of exposure to storm per see (regardless of damage experience), which suggests that households have to suffer damage for their risk preference to be affected. These results are robust across a battery of alternative model specifications and alternative storm damage measures (magnitude of financial damage). We rule out other potential explanations such as health-related and economic shocks. The self-reported storm damage data is broadly confirmed by regional storm damage data provided by the insurance industry. While we cannot identify the channels through which experiencing storm damage affects risk preference from our data, we suggest and discuss some potential channels. The results may have important policy implications as risk preference affects, for instance, individuals' savings and investment behaviour, adoption of self-protection and self-insurance strategies, and technology adoption.
\end{abstract}

Keywords: Extreme weather, risk preference, risk seeking, storm damage, panel data JEL-codes: C23, D03, D81, Q54

${ }^{\mathrm{a} C e n t r e ~ f o r ~ E u r o p e a n ~ E c o n o m i c ~ R e s e a r c h ~(Z E W), ~ L ~ 7, ~ 1, ~} 68161$ Mannheim, Germany

bCorresponding author (kahsay@zew.de, phone +49-621-1235376, fax +49-621-1235226) 


\section{Acknowledgements}

We thank Kibrom A. Abaya, Carlo Gallier, Francois Laisney, and the participants at the young researchers workshop "Environmental and Resource Economics” of the Verein für Socialpolitik for helpful comments and suggestions. Financial support of the German Ministry for Education and Research (BMBF) under grant 01LA1113C is gratefully acknowledged. The funding source had no involvement in study design, collection, analysis and interpretation of the data, and writing of the article. 


\section{Introduction}

There is a growing literature that argues individuals' risk preference may change in response to experiencing socio-economic and natural shocks such as natural disasters, civil wars, and both macroeconomic and financial crises. On the one hand, such shocks may increase risk vulnerability through updating background risk (Gollier and Pratt, 1996). On the other hand, individuals may exhibit risk loving due to variations in the way people evaluate changes in gains and losses (Kahneman and Tversky, 1979; Tversky and Kahneman 1992), complementarity of independent risks (Quiggin, 2003), or emotional reaction (Lerner and Keltner, 2001). The empirical literature examining the impact of shocks on risk preference yields mixed results with regard to the direction of the change. Some studies find increase in risk aversion after experiencing macroeconomic shocks (Malmendier and Nagel, 2011), financial crises (Guiso et al., 2013), land reform (Di Tella et al., 2007), violence (Callen et al., 2014), and natural disasters (Andrabi and Das, 2010; Cassar et al., 2011; Cameron and Shah, 2015). However, other studies find that experiencing violence (Voors et al., 2012) and natural disasters (Eckel et al., 2009; Hanaoka et al., 2014; Page et al., 2014) makes individuals more risk loving. Some studies find no significant effect of drought or excess rainfall (Voors et al., 2012) and tsunami (Callen, 2011) on risk preference while others find heterogeneous impacts after exposure to a natural disaster (Li et al., 2011; Ali Bchir and Willinger, 2013).

In light of these mixed theoretical predictions and empirical evidence, it remains an empirical question whether experiencing socio-economic or natural shocks affect risk preference. Understanding this effect is very important as risk preference affects, for instance, individuals’ savings and investment behaviour (Rosenzweig and Stark, 1989), adoption of self-protection and self-insurance strategies (Dionne and Eeckhoudt, 1985), and technology adoption (Liu, 2013).

In this paper, we investigate the impact of experiencing storm damages on risk preference of households using a longitudinal dataset from a standardized survey among German households conducted in 2012 and 2014. Much of the damage from natural disasters in Germany comes from storm and hail. For instance, in 2007 a total insured damage of 2.06 billion euros in the German economy (GDV, 2015) was caused by storms. The period between 2012 and 2014 also saw one of the largest storm events; namely, a storm called "Christian" in October 2013. Our identification strategy exploits the differences in storm damage on household level. In particular, we compare risk preference of households that 
report a storm damage only in the second survey wave (treatment group) with households that do not report such damage in any of the survey periods (control group). We find an increase in risk taking among households who experienced storm damage between the survey waves. We do not find evidence of exposure to storm per see (regardless of damage experience) which suggests that households have to suffer damage for their risk preference to be affected. These results are robust across a battery of specifications, for instance, including socioeconomic variables as well as regional level and individual fixed effects, alternative definitions of the control group, alternative estimation models such as propensity score matching and ordered probit models, and alternative measure of storm related damage (magnitude of financial damage). We find that the self-reported damage correlates quite well with storm insurance data and the treatment effect is stronger for regions which were highly affected by the storm "Christian” in October 2013. We rule out alternative explanations such as health, economic or other extreme weather shocks.

While we cannot identify the channels through which experiencing storm damage affects risk preference from our data, we suggest some potential channels in the discussion of the results. These include emotional changes, reception of compensation from insurance, and the difference between expected and actual storm damage.

Our paper adds to the growing empirical evidence on the impact of socio-economic and natural shocks on risk preference. Firstly, while many of the aforementioned studies focus on developing countries, our paper contributes to the very limited evidence on the effect of natural hazard on risk preference in a developed country context. We are aware of three studies focusing on the effects of natural hazards on risk preference in the US (Eckel et al., 2009), Australia (Page et al., 2014), and Japan (Hanaoka et al., 2014). For Europe, there is no empirical evidence on the implications of natural hazards on risk preference so far. Secondly, most of the previous studies use cross-section data while the longitudinal nature of our data enables us to follow both the treatment and control groups before and after the storm damage happened.

The rest of the paper is organized as follows. Section 2 presents the data and empirical method used for this analysis while Section 3 presents and discusses the empirical results. Section 4 presents and discusses robustness checks. Section 5 concludes. 


\section{Data and Econometric Method}

\subsection{Data Description}

The data we use for this study comes from a nation-wide longitudinal household survey among representative German households. A total of 4496 households were interviewed via either an online or TV-based ${ }^{1}$ questionnaire in two rounds (2012 and 2014). Among others, the survey includes measures of risk preference of the heads of households as well as the households' experiences with different extreme weather events such as floods and storms. Similarly, the survey includes various socio-demographic variables as well as economic and health-related concerns. The availability of a novel longitudinal dataset covering risk preference and information on extreme weather experiences allows a detailed empirical analysis of this topic in a developed country context. A more detailed exposition on the sampling design is given in Osberghaus and Philippi (2015) and Osberghaus (2015). Table 1 presents the share of households who experienced storm damage in 2012 and 2014.

Table 1: Overall distribution of storm-related financial and health damage experience across sample households

\begin{tabular}{lll}
\hline & \multicolumn{2}{l}{ Survey } \\
\cline { 2 - 3 } & $\mathbf{2 0 1 2}$ & $\mathbf{2 0 1 4}$ \\
\hline Reporting financial or health damage from storm & 1,439 & 1,510 \\
No reporting of financial or health damage from storm & 4,928 & 4,921 \\
Total number of households $^{\mathrm{a}}$ & 6,367 & 6,431 \\
Share of households who experience damage from storm, in \% & 22.60 & 23.48
\end{tabular}

a) The total number of households is higher than the sample size in our analysis because some households participated only in one survey wave.

Households were asked to indicate if any of the listed events (including storms) have ever caused financial damage or health damage such that a doctor was consulted. The formulation of the question does not allow conclusions about the timing of the damage experience, but elicits the occurrence of the mere damage at some point in time after the first survey, yet, before the second survey. Out of the 4,496 sample households, 583 report storm damage both in 2012 and 2014, 2,986 households did not experience such a damage in any of the survey periods, and 457 households report no storm damage in 2012 but in 2014 (this means they must have experienced a damage in between). The remaining 470 households report having

\footnotetext{
${ }^{1}$ For the purpose of representativeness, households in the panel without internet access are provided with a device connected with their TV. Thereby they can participate in the survey by TV.
} 
experienced damage in the first wave, while in the second wave, they report never having experienced such damage.

Risk taking is measured on an 11-point Likert scale. Households were asked to indicate the degree of their risk taking on a scale from 0 (risk averse) to 10 (very prepared to take risks). The fact that our risk taking variable is a self-reported measure may raise a concern on whether it reflects the underlying risk preference of households. However, many studies show that such measure is a reliable predictor of the actual risk seeking behaviour (e.g., Barsky et al., 1997; Donkers et al., 2001; Dohmen et al., 2011). For instance, Dohmen et al. (2011) compare the results of risk taking using an identical 11-point scale survey measure with an incentivized field experiment based on Holt and Laury (2002) among German individuals. They conclude that the used survey measure is a good predictor of the actual risk-taking behaviour and hence is a valid instrument to infer actual risk-taking behaviour.

We are interested in estimating the risk preference of households who report storm damage between 2012 and 2014 as compared to those who did not report storm damage in any of the surveys. For convenience, we label 457 households who report storm damage between 2012 and 2014 as our treatment group, while the 2,986 households who did not report storm damage in both survey periods are our main control group. The 583 households who report storm damage both in 2012 and 2014 are included as additional control group (see robustness checks). The 470 households who report damage in 2012 but no longer in 2014 require special attention (see robustness checks) and hence are excluded from our main analysis.

Table 2 compares risk taking and other socio-demographic variables of the two household groups at the baseline (2012). The comparison shows that both treatment and control groups have statistically similar pre-treatment risk preference. Both groups are also similar in terms of pre-treatment gender, education, and employment status. However, households in the treatment group have higher income, household size, and older household head than the control group. 
Table 2: Risk preferences in treatment and control groups in base year (2012 survey)

\begin{tabular}{llll}
\hline & $\begin{array}{l}\text { Control } \\
\text { Group }\end{array}$ & $\begin{array}{l}\text { Treatment } \\
\text { Group }\end{array}$ & Difference \\
\hline Risk preference & 5.819 & 5.798 & 0.021 \\
Gender (1 if female) & $(0.038)$ & $(0.092)$ & $(0.103)$ \\
& 0.310 & 0.280 & 0.030 \\
Age† & $(0.009)$ & $(0.021)$ & $(0.023)$ \\
& 52.009 & 53.260 & $-1.251^{*}$ \\
Income & $(.244)$ & $(0.595)$ & $(0.665)$ \\
& 2794.12 & 3081.23 & $-287.12^{* * *}$ \\
Household size & $(26.15)$ & $(64.51)$ & $(70.984)$ \\
& 2.137 & 2.401 & $-0.264 * * *$ \\
Education (1 if higher & $(0.020)$ & $(0.054)$ & $(0.054)$ \\
educated) & 0.477 & 0.454 & 0.024 \\
Employment status $(1$ if & $(0.009)$ & $(0.023)$ & $(0.025)$ \\
employed) & 0.712 & 0.698 & 0.014 \\
\hline
\end{tabular}

$\dagger \quad$ When we include households who reported storm damage in both survey rounds into our control group (see robustness checks in section 4), the age difference disappears.

\subsection{Econometric Method and Identification Strategy}

The identification strategy exploits storm-related financial or health damage reported by the heads of households. We use a difference-in-differences approach and compare risk preference of households that report storm damage (treatment group) between the survey rounds with those that did not report storm damage (control group) before and during that period. As compared to a simple comparison between the treatment and control groups in the second period, this approach removes potential biases that may arise from permanent differences between the two groups and trends. More explicitly, we estimate the following difference-in-differences (DID) equation:

$Y_{i t}=\beta_{0}+\beta_{1}$ Treatment $+\beta_{2}$ Post $+\beta_{3}$ (Treatment $*$ Post $)+\beta_{4} X_{i t}+\alpha_{r}+\varepsilon_{i t}(1)$

Where $Y_{i t}$ is risk preference of household $i$ at time $t$. Treatment is a dummy variable for households who report storm damage after 2012 (equal to one if the household reports storm damage after the 2012 survey, zero otherwise). Post stands for a period after the treatment households reported storm damage (a dummy that takes a value equal to one for 2014, zero otherwise). $\beta_{1}$ captures potential pre-treatment differences in risk preference between the treatment group and control group households. Our main parameter of interest, $\beta_{3}$, captures the interaction effect between storm damage and the latter survey year (2014). $\beta_{4}$ captures the effect of other time-varying and time-invariant covariates. $\alpha_{r}$ captures regional level fixed 
effects, while $\varepsilon_{i t}$ captures other unobserved factors that may induce heterogeneity in risk preference.

Our main parameter of interest, $\beta_{3}$, measures the treatment effect, which is the effect of storm damage on risk preference. Considering storm experience as a natural hazard exogenous to households, the longitudinal nature of our data, and our identification strategy, we believe that our results measure the appropriate causality. We estimate the model in (1) with OLS. Since our dependent variable is an ordinal variable measured on an 11-point Likert scale, we also re-estimate the model in (1) using an ordered probit model. All these specifications give the same results. Similarly, re-estimating our model with individual fixed effects does not change our main result.

One matter of concern with our storm-related financial and health damage variable is the fact that it is self-reported and may be affected by unobserved individual characteristics. Namely, some heads of households may recall a storm event and the consecutive financial damage better than others. Hence, our data can only serve as a rough measure for the actual exposure to storm events in Germany. Nevertheless, we expect these individual-specific effects to be time-invariant and thus not affecting our main results. We also estimate our model using propensity score matching in order to mitigate the effect of differences in the propensity to report storm damage. Moreover, we alternatively use insured damage from the storm “Christian” in October 2013 as reported by insurance companies (GDV, 2015). For instance, Schleswig-Holstein and Lower Saxony are the two regions afflicted with the largest property damage by “Christian”, followed by Hamburg and Bremen. On the other hand, regions such as Saxony and Bavaria experienced the smallest property damage for this event. We therefore categorize regions based on the intensity of actual property damage. We find that the treatment effect is very large for regions that are hit hardest while this effect is insignificant for regions where the damage is minor. ${ }^{2}$ In addition, the propensity to report storm damage in our survey is highest for regions affected by “Christian”.

\section{Estimation Results}

Table 3 presents estimation results for risk preference. In column 1, we present a basic model with only the treatment and time variables. In column 2, we add socio-demographic controls

\footnotetext{
${ }^{2}$ These results are not presented here, but they are available from the authors upon request.
} 
while in column 3, we include regional level fixed effects. Column 4 presents estimates with individual fixed effects.

Table 3: OLS regression of the effect of storm damage experience on risk preference, difference-in-differences estimates ${ }^{3}$

\begin{tabular}{|c|c|c|c|c|}
\hline Explanatory variables & (1) & $(2)$ & (3) & (4) \\
\hline Treatment & $\begin{array}{l}-0.023 \\
(0.099)\end{array}$ & $\begin{array}{l}-0.074 \\
(0.105)\end{array}$ & $\begin{array}{l}-0.079 \\
(0.106)\end{array}$ & \\
\hline Post & $\begin{array}{l}-0.119 * * * \\
(0.034)\end{array}$ & $\begin{array}{l}-0.138 * * * \\
(0.039)\end{array}$ & $\begin{array}{l}-0.107 * * \\
(0.054)\end{array}$ & $\begin{array}{l}-0.103 * * * \\
(0.036)\end{array}$ \\
\hline Treatment * Post & $\begin{array}{l}0.231 * * \\
(0.095)\end{array}$ & $\begin{array}{l}0.225 * * \\
(0.109)\end{array}$ & $\begin{array}{l}0.245^{* *} \\
(0.110)\end{array}$ & $\begin{array}{l}0.235^{* *} \\
(0.102)\end{array}$ \\
\hline Female & & $\begin{array}{l}-0.459 * * * \\
(0.074)\end{array}$ & $\begin{array}{l}-0.467 * * * \\
(0.074)\end{array}$ & \\
\hline Age & & $\begin{array}{l}0.015^{* * *} \\
(0.003)\end{array}$ & $\begin{array}{l}0.015^{* * *} \\
(0.003)\end{array}$ & \\
\hline Ln (income) & & $\begin{array}{l}0.263 * * * \\
(0.070)\end{array}$ & $\begin{array}{l}0.271^{* * *} \\
(0.071)\end{array}$ & $\begin{array}{l}0.039 \\
(0.124)\end{array}$ \\
\hline Household size & & $\begin{array}{l}-0.056^{*} \\
(0.032)\end{array}$ & $\begin{array}{l}-0.058^{*} \\
(0.032)\end{array}$ & $\begin{array}{l}-0.035 \\
(0.057)\end{array}$ \\
\hline Education & & $\begin{array}{l}0.163 * * \\
(0.068)\end{array}$ & $\begin{array}{l}0.161^{* *} \\
(0.068)\end{array}$ & $\begin{array}{l}-0.053 \\
(0.200)\end{array}$ \\
\hline Employment status & & $\begin{array}{l}-0.003 \\
(0.090)\end{array}$ & $\begin{array}{l}-0.002 \\
(0.090)\end{array}$ & $\begin{array}{l}0.076 \\
(0.148)\end{array}$ \\
\hline Region fixed effects & No & No & Yes & No \\
\hline $\begin{array}{l}\text { Individual fixed } \\
\text { effects }\end{array}$ & No & No & No & Yes \\
\hline Constant & $\begin{array}{l}5.819 * * * \\
(0.038)\end{array}$ & $\begin{array}{l}3.136 * * * \\
(0.532)\end{array}$ & $\begin{array}{l}3.258 * * * \\
(0.570)\end{array}$ & $\begin{array}{l}0.006^{*} \\
(0.003)\end{array}$ \\
\hline R-squared & 0.001 & 0.033 & 0.037 & 0.004 \\
\hline $\begin{array}{l}\text { Number of } \\
\text { observations }\end{array}$ & 6,879 & 5,733 & 5,729 & 5,730 \\
\hline
\end{tabular}

Note: $* * *, * *$, and $*$ represents significance level at $1 \%, 5 \%$, and $10 \%$ respectively. Standard errors are clustered at household level. The region fixed effects comprises the 16 regions in Germany. Treatment, Female, and Age variables are dropped in the fixed effects estimation due to collinearity. Replacing household size with number of children or including number of children under 18 does not change our results.

As can be seen from column 1 of table 3, experiencing storm damage increases risk seeking of households as compared to the control group. The estimated results are stable with the inclusion of socio-demographic controls as well as regional level and individual fixed effects. This result is in line with previous studies who also find an increase in risk taking after exposure to violence and natural disasters (Eckel et al., 2009; Voors et al., 2012; Hanaoka et al., 2014; Page et al., 2014). Eckel et al. (2009) investigate the link between experience with

\footnotetext{
${ }^{3}$ We do not find any significant effect of experiencing extreme weather related damage on patience of households in our study.
} 
Katrina hurricane and individual risk preference among evacuees shortly after they were evacuated and transported to Houston. They find that the evacuees exhibit risk-loving behaviour. Similarly, Hanaoka et al. (2014) find that people who experienced larger intensity of earthquake in Japan became more risk tolerant. Both studies suggest that this could be due to emotional responses to natural disasters. Hanaoka et al. (2014) further find that men who live in locations hit by larger intensity of earthquake become mentally less healthy (standardized average of stress, depression, and sleep problems). They suggest that this may be in line with emotional responses. Page et al. (2014) refer to prospect theory and find evidence for the postulation of increased risk taking after suffering large losses from flood in their sample of households in Brisbane, Australia. On the violence side, Voors et al. (2012) investigate risk and time preferences of individuals who experienced civil war in Burundi. They find that individuals exposed to the violence are more risk-seeking and have higher discount rates while they also display more altruistic behaviour towards their neighbors. However, our result is in contrast to other studies that find a significant increase of risk aversion after experiencing natural hazards and socio-economic shocks. For instance, Malmendier and Nagel (2011) find that early life financial experiences such as the Great Depression led to conservative investing behaviour in later life in the US (Malmendier and Nagel 2011). Their results suggest an increase in risk aversion. Similarly, Cameron and Shah (2015) compare individuals in villages in Indonesia that experience natural disasters (earthquake and flood) and find that they exhibit higher levels of risk aversion as compared to similar individuals in villages that did not experience such disasters. A number of other studies (Di Tella et al., 2007; Callen et al., 2014; Andrabi and Das, 2010; Cassar et al., 2011; Cameron and Shah, 2015) also find an increase in risk aversion in response to natural disasters, violence, or land reforms.

The results regarding the control variables are consistent with the findings in previous literature. We find that female respondents and those with higher family size are less likely to exhibit risk taking while we find positive effects of income and education. The positive effect of age seems to be in contrast with previous studies (e.g., Dohmen et al., 2011; Voors et al., 2012; Hanaoka et al., 2014; Cameron and Shah, 2015). However, the literature on age and risk taking is far from clear. For instance, Guiso and Paiella (2008) and Mather et al. (2012) find older people are more risk taking than younger people.

Our data does not enable us to identify the channels through which experiencing storm damage affects risk preference. We suggest some potential channels in the following. 
Experiencing a natural disaster may change the way the cognitive and the emotional systems are involved in decision-making (Loewenstein et al. 2001) and hence individuals may put a higher weight on emotions after trauma, inducing changes in preferences. In line with this, Eckel et al. (2009) argued that the risk loving behaviour among individuals affected by hurricane Katrina is explained by the emotional state of the respondents shortly after the hurricane. Another potential channel could be compensation from storm insurance. Storm insurance coverage is bundled with other hazards such as fire. Hence, a great majority of the households are insured against storm. The storm insurance penetration in Germany is at about 92\% for home and $76 \%$ for contents insurance (GDV, 2015). Therefore, receiving compensation for storm damage in between 2012 and 2014 might induce households to be more risk seeking. This is also in line with Cameron and Shah (2013) who find that remittances mitigate the effect of natural disaster on risk aversion. Finally, individuals might have overestimated the expected consequences of negative shocks. However, experiencing damage from these events might induce individuals to relax their risk taking. ${ }^{4}$

\section{Robustness Checks}

We perform a battery of robustness checks. The main results are presented in table 4, focusing on the specification including individual control variables and regional fixed effects. The coefficients of the control variables (available upon request) do not change significantly across the robustness checks and hence are not presented in detail. We first present estimation results including households that report storm damage in both survey waves into the control group (robustness check 1 in table 4). The estimated effect is similar to the one reported in table 3 .

\footnotetext{
${ }^{4}$ Another line of literature argues that exposure to natural hazards affects risk preferences through changing the environment with which people interact (Douglas and Wildavsky, 1982). Other explanations include neurobiological effects (van IJzendoorn et al., 2010) and increasing cortisol levels (Kandasamy et al., 2014). Similarly, Voors et al. (2012) suggest selection effects, changes in beliefs, social structure, and preferences as potential explanations for the observed risk-loving behavior after exposure to violence in their study.
} 
Table 4: Robustness checks of regression of risk preference

\begin{tabular}{|c|c|c|c|c|}
\hline & \multicolumn{4}{|c|}{ Robustness checks } \\
\hline & (1) & (2) & (3) & (4) \\
\hline $\begin{array}{l}\text { Explanatory } \\
\text { variables }\end{array}$ & $\begin{array}{l}\text { Extended } \\
\text { control } \\
\text { group }\end{array}$ & $\begin{array}{l}\text { Ordered } \\
\text { probit }\end{array}$ & $\begin{array}{l}\text { Exposure per } \\
\text { se }\end{array}$ & $\begin{array}{l}\text { Magnitude } \\
\text { of financial } \\
\text { damage }\end{array}$ \\
\hline Treatment & $\begin{array}{l}-0.055 \\
(0.105)\end{array}$ & $\begin{array}{l}-0.042 \\
(0.054)\end{array}$ & $\begin{array}{l}0.006 \\
(0.157)\end{array}$ & $\begin{array}{l}-0.027 \\
(0.109)\end{array}$ \\
\hline Post & $\begin{array}{l}-0.095^{*} \\
(0.049)\end{array}$ & $\begin{array}{l}-0.073^{* * *} \\
(0.020)\end{array}$ & $\begin{array}{l}0.024 \\
(0.132)\end{array}$ & $\begin{array}{l}-0.099 * \\
(0.053)\end{array}$ \\
\hline Treatment $*$ Post & $\begin{array}{l}0.226^{* *} \\
(0.108)\end{array}$ & $\begin{array}{l}0.118^{* *} \\
(0.055)\end{array}$ & $\begin{array}{l}-0.020 \\
(0.151)\end{array}$ & $\begin{array}{l}0.142 * * \\
(0.060)\end{array}$ \\
\hline Control variables & Yes & Yes & Yes & Yes \\
\hline $\begin{array}{l}\text { Region fixed } \\
\text { effects }\end{array}$ & Yes & Yes & Yes & Yes \\
\hline Constant & $\begin{array}{l}3.179 * * * \\
(0.533)\end{array}$ & & $\begin{array}{l}3.653 * * * \\
(1.191)\end{array}$ & $\begin{array}{l}3.348 * * * \\
(0.573)\end{array}$ \\
\hline R-squared & 0.038 & $0.009^{\mathrm{a}}$ & 0.033 & 0.038 \\
\hline $\begin{array}{l}\text { Number of } \\
\text { observations }\end{array}$ & 6,676 & 5,729 & 1,588 & 5,668 \\
\hline
\end{tabular}

***, **, and $*$ represents significance level at $1 \%, 5 \%$, and $10 \%$ respectively. Standard errors are clustered at household level. The region fixed effects comprises the 16 regions in Germany.

\section{a) Pseudo R-squared for ordered probit estimation}

Since our dependent variable, risk taking, is measured on an 11-point Likert scale (0 to 10), we re-estimate the model using the ordered probit model. Robustness check (2) in table 4 (see Appendix table A1 for complete estimation results) presents the results. They are consistent with the OLS regression results in table 3 demonstrating that experiencing storm damage increases risk taking.

Our treatment variable is reported financial or health-related damage from storm. However, experiencing a storm may affect risk preference regardless of whether they cause damage or not. Hence, we re-define the treatment variable now capturing all households that report having experienced a major storm in 2014, but not in 2012 (with or without damage). Robustness check (3) in table 4 presents these results. We do not find evidence of exposure to storm per se which suggests that households have to suffer damage for their risk preference to be affected.

We also use alternative measures of storm damage. Households were asked the magnitude of financial damage they incurred (in four categories, starting from below 500 euros to above 10,000 euros). We re-estimate our model by replacing the treatment indicator with a 
continuous measure of the magnitude of financial damage. In doing so, we exclude those households that report only health damage and those that do not report the extent of the damage from the estimation. Robustness check (4) in table 4 presents these results. Once again the results are consistent with our main results in table 3.

Although there is no pre-treatment difference in risk taking between the treatment and control groups, we observe some differences in age, income, and household size. Similarly, storm damage experience is self-reported and hence there may be differences in the propensity to report the damage. Thus, we also estimate our model using propensity score matching. Column 1 of table 5 presents propensity score estimates from a probit model while column 2 presents the matching estimate. The propensity score estimates reveal that households that have above average income and household size are associated with a higher probability of reporting storm damage while education of the household head is negatively associated with reporting storm damage. However, gender, age, and employment status do not have any significant effect. The treatment effect in column 2 is consistent with the treatment effect in table 3 above. $^{5}$

\footnotetext{
${ }^{5}$ While we do not have prior periods to test the implication of common trend assumption, we estimate our model by re-defining the treatment and control groups through random draws from our data. We do not find a significant treatment effect - which is expected. Similarly, we estimate our model for a sub-sample of our treatment and control groups with a series of random draws. We find a significant treatment effect which is in line with our identification strategy.
} 
Table 5: Effect of storm damage experience on risk preference, difference-in-differences matching estimates

\begin{tabular}{lll}
\hline Explanatory variables & Probit model & Matching estimate \\
\hline Average treatment effect & & $0.202^{* *}$ \\
Female & 0.037 & \\
& $(0.067)$ & \\
Age & 0.002 & \\
& $(0.003)$ & \\
Ln (income) & $0.223 * * *$ & \\
& $(0.068)$ & \\
Household size & $0.074 * *$ & \\
& $(0.030)$ & \\
Education & $-0.105 *$ & \\
& $(0.062)$ & \\
Employment status & -0.103 & 5796 \\
& $(0.083)$ & $-3.023 * * *$ \\
Constant & $(0.508)$ & \\
Pseudo R-squared & 0.014 & \\
Number of observations & 2,903 & \\
\hline Note: ***, **, and * represents significance level at 1\%, 5\%, and 10\% respectively. \\
Standard errors are clustered at household level.
\end{tabular}

Next, we investigate whether the observed difference in risk taking between the treatment and control groups could be explained by other factors. First, as argued by Callen et al. (2014), mobility and selective migration present natural confounds. We show that location of households is not related with exposure to extreme weather events. Out of 6,404 households who participated in the survey in 2012, 1,924 households did not participate in 2014. It is not clear whether these households did not answer the survey because they did not want to or because they moved to a new address due to exposure to natural hazard. The latter may confound our results. However, we have asked all 6,404 households in 2012 whether and why they have relocated over the past ten years. Out of 2,824 households who moved between 2002 and 2012, one single household reports natural hazards as the only reason. Additional eight households report natural hazards as one of several reasons to relocate. Thus, we believe that migration due to natural hazards is of little relevance in our context.

Second, initial differences in risk taking between the treatment and control groups could result in differences in mitigation behaviour. Such differences in mitigation behaviour could subsequently result in differences in storm damage and hence risk taking. However, this should not be a concern in our case since we do not find any pre-treatment difference in risk taking between the treatment and control groups. 
Third, the observed difference could be explained by other factors such as health and economic shocks. We consider reported concern with regard to own health and economy as a proxy for health-related and economic shocks respectively. We re-define the treatment group as households who answered 'very important' to own economic/health-related concerns in 2014 (but not in 2012) while our control group comprises households that did not answer 'very important' to these concerns in both surveys. We re-estimate our models by using these variables as a treatment instead of a storm. We do not find any significant difference between the treatment and control groups in risk taking due to economic or health-related shocks (columns 1 and 2 of table 6 ).

Table 6: Effect of other floods, economic, or health shocks on risk preference, difference-in-differences estimates

\begin{tabular}{llll}
\hline Explanatory variables & $(1)$ & $(2)$ & $(3)$ \\
\cline { 2 - 4 } & Economy & Health & Flood \\
\hline Treatment & -0.043 & 0.001 & 0.089 \\
& $(0.101)$ & $(0.108)$ & $(0.107)$ \\
Post & -0.099 & -0.115 & -0.074 \\
& $(0.065)$ & $(0.077)$ & $(0.057)$ \\
Treatment $*$ Post & -0.029 & 0.126 & 0.010 \\
& $(0.099)$ & $(0.106)$ & $(0.105)$ \\
Control variables & Yes & Yes & Yes \\
Region fixed effects & Yes & Yes & Yes \\
Constant & $3.196 * * *$ & $2.636^{* * *}$ & $2.813^{* * *}$ \\
R-squared & $(0.647)$ & $(0.752)$ & $(0.598)$ \\
Number of observations & 4,016 & 0.045 & 0.039 \\
\hline
\end{tabular}

Note: $* * *, * *$, and $*$ represents significance level at $1 \%, 5 \%$, and $10 \%$ respectively. Standard errors are clustered at household level. The region fixed effects comprises the 16 regions in Germany.

Similarly, we investigate whether experiencing damage from other extreme weather effect (flood) explains the observed difference in risk taking between the two groups. As we can see from column 3 of table 6 , we do not find significant differences between the treatment and control groups in risk taking due to flood-related damage experience. The finding that experiencing damage from the storm affects households risk taking but not flood requires further investigation. We present speculative explanations for why this might be the case. Many households are relatively certain in estimating their vulnerability towards floods (falsely or correctly), for instance, due to their location. This would imply that household may already internalize the perceived threat from flood. This is unlikely to be the case for storm, as the vulnerability is much more difficult to evaluate ex ante. Nevertheless, we hope further study will shed light on this issue. 
Finally, we have 470 households who report storm damage in 2012, but not in 2014. With our question on storm damage experience, we ask households whether they have ever experienced financial or health damage from storms without specifying the year of the damage experience. Thus, the storm damage report of this group of households seems implausible since they should have reported damage experience in 2014, too. We suggest three potential explanations. Firstly, this group of households may interpret the storm damage question as only referring to the period after the first round survey. Thus, they may answer 'no' to our question if they did not experience storm damage after 2012. If this is the case, we can consider them as part of our extended control group that includes households who report damage in both survey rounds. However, including the 470 households in the control group in our main analysis does not change our results. We also do not find any significant difference in risk taking between this group of households and households who report storm damage in both survey waves. Secondly, it might be the case that the last time they experienced storm damage is some years ago as recalled in 2012, but they could not recall it in 2014. Finally, following Ashraf et al. (2006), such implausible answering could be mostly due to noise since it does not correlate with risk taking as confirmed in our estimation. That is, we compare the risk taking preference of these 470 households with our main and extend control groups. A positive effect of this treatment on risk taking would confound our main results. However, we do not find any significant difference in risk taking among these groups (detailed results available upon request). This may imply that the change in risk taking is not affected by the potential to remember storm damage experience. We hope that further study will shed light on this issue.

\section{Conclusions}

This paper investigates the effect of self-reported storm damage on risk preference of households. We use detailed longitudinal household survey data that comes from a novel representative nation-wide survey in Germany. We exploit the longitudinal nature of the data and compare risk taking of households between those that report storm-related financial or health damage between the survey waves (i.e., between 2012 and 2014) and those that did not report storm damage over both survey periods. We find that storm damage increases risk loving. These results are robust to adding a number of socio-demographic control variables and alternative specifications. We find no evidence that these results are driven by experiencing other extreme weather events such as floods. Similarly, we do not find evidence 
that the observed difference in risk talking is due to other economic or health-related shocks. These results contribute to the growing literature on the effect of natural hazard and socioeconomic shocks on risk preference by presenting evidences from a highly developed country context.

We believe that these results offer an interesting insight on the importance of extreme weather on risk preference although care should be taken in interpreting our results. Firstly, in contrast to the standard economic assumption that preferences are stable, these results may imply that preferences may change due to exposure to extreme weather. However, whether this change is permanent or temporary is an interesting question which we cannot answer from our data. As argued by Callen et al. (2014), it may be the case that individuals change their risk taking for a period of time due to susceptibility of their behaviour instead of their risk preference. Secondly, there could be differences among households in terms of recalling damage from storm events. This may be the case given some of the households who reported damage in 2012 but not in 2014. Thus, there may be a tendency for some households to recall these events more likely than others. Although our matching estimation mitigates these effects, we cannot completely rule out the possibility that the recall capacity may be correlated with unobservable time variant factors.

\section{References}

Andrabi, Tahir, and Jishnu Das. 2010. "In Aid We Trust: Hearts and Minds and the Pakistan Earthquake of 2005.” Policy Research Working Paper 5440, The World Bank.

Ashraf, N., Karlan, D. and Yin, W. 2006. "Tying Odysseus to the mast: Evidence from a commitment savings product in the Philippines.” The Quarterly Journal of Economics, 635-672.

Barsky, Robert B., F. Thomas Juster, Miles S. Kimball, and Matthew D. Shapiro. 1997. "Preference Parameters and Behavioral Heterogeneity: An Experimental Approach in the Health and Retirement Survey.” The Quarterly Journal of Economics, 112 (2): 537-579.

Bchir, Mohamed A., and Marc Willinger. 2013. "Does the exposure to natural hazards affect risk and time preferences? Some insights from a field experiment in Peru." LAMETA working paper serie, 2013(04): University of Montpellier, France.

Callen, Michael. 2011. “Catastrophes and Time Preference: Evidence From the Indian Ocean Earthquake.” Unpublished manuscript, University of California at San Diego. 
Callen, Michale. 2015. "Catastrophes and time preference: Evidence from the Indian Ocean Earthquake.” Journal of Economic Behavior \& Organization Volume 118, October 2015, Pages 199-214

Callen, Michael, Mohammad Isaqzadeh, James D. Long, and Charles Sprenger. 2014. "Violence and Risk Preference: Experimental Evidence from Afghanistan.” American Economic Review 104(1):123-48.

Cameron, L. and Shah, M. 2015. "Risk- Taking Behavior in the Wake of Natural Disasters." The journal of human resources 50(2): 484-515

Cassar, A., Healy, A., \& Von Kessler, C. 2011. “Trust, risk, and time preferences after a natural disaster: experimental evidence from Thailand.” Working paper

Dionne, Georges, and Louis Eeckhoudt. 1985. "Self-insurance, Self-protection and Increased Risk Aversion.” Economics Letters, 17(12): 39 - 42.

Di Tella, Rafael, Sebastian Galiani, and Ernesto Schargrodsky. 2007. "The Formation of Beliefs: Evidence from the Allocation of Land Titles to Squatters.” Quarterly Journal of Economics 122(1):209-241.

Dohmen, Thomas, Armin Falk, David Huøman, Uwe Sunde, Jürgen Schupp, and Gert G. Wagner. 2011. “Individual risk attitudes: measurement, determinants and behavioral consequences.” Journal of the European Economic Association, 9(3): 522-550.

Douglas, Mary, and Aaron Wildavsky. 1982. Risk and Culture: An Essay on Selection of Technological and Environmental Dangers. California University Press, Berkeley.

Donkers, Bas, Bertrand Melenberg, and Arthur Van Soest. 2001. Estimating Risk Attitudes Using Lotteries: A Large Sample Approach.” Journal of Risk and Uncertainty, 22(2):165195.

Eckel, Catherine, Mahmoud El- Gambal, and Rick Wilson. 2009. "Risk Loving After the Storm: A Bayesian- Network Study of Hurricane Katrina Evacuees.” Journal of Economic Behavior and Organization 69(2):110-24.

GDV, 2015. “Naturgefahrenreport 2015”. http://www.gdv.de/2015/10/wohngebaeudeversicherer-zahlten-12-milliarden-euro-fuer-unwetterschaeden/, Gesamtverband der Deutschen Versicherungswirtschaft, German Insurance Association.

Gollier, Christian, and John W Pratt. 1996. "Risk Vulnerability and the Tempering Effect of Background Risk.” Econometrica, 64(5): 1109-1123. 
Guiso, Luigi, and Monica Paiella. 2008. "Risk Aversion, Wealth, and Background Risk. Journal of the European Economic Association, 6(6): 1109-50.

Hanaoka, C., Shigeoka, H., \& Watanabe, Y. 2014. "Do risk preferences change? Evidence from panel data before and after the great east Japan earthquake. Evidence from Panel Data Before and After the Great East Japan Earthquake.” Working paper.

Kahneman, Daniel, and Amos Tversky. 1979. "Prospect Theory: An analysis of Decision Under Risk.” Econometrica, 47(2): 263-291.

Kandasamy, Narayanan, Ben Hardy, Lionel Page, Markus Schaffner, Johann Graggaber, Andrew S. Powlson, Paul C. Fletcher, Mark Gurnell, and John Coates. 2014. “Cortisol shifts financial risk preferences.” PNAS, Early edition

Lerner, Jennifer and Dacher Keltner. 2001. “Fear, Anger, Risk" Journal of Personality and Social Psychology, 2001, 81 (1), 146-159.

Li, Jin-Zhen, Shu Li, and Huan Liu. 2011. "How Has the Wenchuan Earthquake Influenced People’s Intertemporal Choices?” Journal of Applied Social Psychology, 41(11): 2739_ 2752.

Liu, Elaine. 2013. "Time to Change What to Sow: Risk Preferences and Technology Adoption Decisions of Cotton Farmers in China.” Review of Economics and Statistics 95(4):1386-403.

Loewenstein, George F., Elke U.Weber, Christopher K. Hsee, and Ned Welch. 2001. "Risk as feelings.” Psychological Bulletin, 127(2): 267-286.

Malmendier, U. and Stefan Nagel. 2011. "Depression Babies: Do macroeconomic Experiences Affect Risk Taking?” The Quarterly Journal of Economics 126, 373-416.

Mather, Mara, Nina Mazar, Marissa A.Gorlick, Nichole R.Lighthall, Jessica Burgeno, Andrej Schoeke, and Dan Ariely. 2012. "Risk preferences and aging: The "Certainty Effect" in older adults’decision making.” Psychology and Aging, 27: 801-816.

Meier, S., \& Sprenger, C. D. 2015. ”Temporal stability of time preferences.” Review of Economics and Statistics, 97(2), 273-286.

Osberghaus, D. 2015. “The determinants of private storm mitigation measures in Germany Evidence from a nationwide survey.” Ecological Economics 110: 36-50.

Osberghaus, D., \& Philippi, A. 2015. "Klimawandel in Deutschland: Risikowahrnehmung und Anpassung in privaten Haushalten 2012 und 2014. ” Mannheim, Germany. 
Page, L., Savage, D., \& Torgler, B. 2014. "Variation in risk seeking behaviour following large losses: A natural experiment.” European Economic Review, 71, S. 121-131.

Quiggin, J. 2003. “Background Risk in Generalized Expected Utility Theory.” Economic Theory, 22, 607-611.

Rosenzweig, Mark, and Oded Stark. 1989. “Consumption Smoothing, Migration, and Marriage: Evidence from Rural India.” Journal of Political Economy 97(4):905-26.

Tversky, A., \& Kahneman, D. 1992. “Advances in Prospect Theory: Cumulative Representation of Uncertainty.” Journal of Risk and Uncertainty, 5, 297-323.

van IJzendoorn, Marinus H., Kristin Caspers, Marian J. Bakermans- Kranenburg, Steven R.H. Beach, and Robert Philibert. 2010. "Methylation Matters: Interaction Between Methylation Density and Serotonin Transporter Genotype Predicts Unresolved Loss or Trauma.” Biological Psychiatry, 68(5): 405-407.

Voors,M.J., Eleonora E. M. Nillesen, Philip Verwimp, Erwin H. Bulte, Robert Lensink, and Daan P. Van Soest. 2012. "Violent Conflict and Behavior: A Field Experiment in Burundi.” American Economic Review 102(2): 941-964 


\section{Appendix}

Table A1: Effect of storm damage experience on risk preference. difference-in-differences estimates (ordered probit regression)

\begin{tabular}{|c|c|c|c|}
\hline Explanatory Variables & (1) & (2) & (3) \\
\hline \multirow[t]{2}{*}{$\beta_{1}$ Treatment } & -0.016 & -0.043 & -0.042 \\
\hline & $(0.049)$ & $(0.053)$ & $(0.054)$ \\
\hline \multirow[t]{2}{*}{$\beta_{2}$ Post } & $-0.062 * * *$ & $-0.073 * * *$ & $-0.073 * * *$ \\
\hline & $(0.017)$ & $(0.020)$ & $(0.020)$ \\
\hline \multirow[t]{2}{*}{$\beta_{3}($ Treatment $*$ Post $)$} & $0.119 * *$ & $0.118 * *$ & $0.118 * *$ \\
\hline & $(0.047)$ & $(0.054)$ & $(0.055)$ \\
\hline \multirow[t]{2}{*}{ Female } & & $-0.240 * * *$ & $-0.246 * * *$ \\
\hline & & $(0.037)$ & $(0.037)$ \\
\hline \multirow[t]{2}{*}{ Age } & & $0.008 * * *$ & $0.008 * * *$ \\
\hline & & $(0.002)$ & $(0.002)$ \\
\hline \multirow[t]{2}{*}{ Ln(income) } & & $0.131 * * *$ & $0.137 * * *$ \\
\hline & & $(0.036)$ & $(0.036)$ \\
\hline \multirow[t]{2}{*}{ Household size } & & $-0.028 *$ & $-0.030 *$ \\
\hline & & $(0.016)$ & $(0.016)$ \\
\hline \multirow[t]{2}{*}{ Education } & & $0.087 * *$ & $0.084 * *$ \\
\hline & & $(0.034)$ & $(0.035)$ \\
\hline \multirow[t]{2}{*}{ Employment status } & & 0.004 & -0.001 \\
\hline & & $(0.046)$ & $(0.046)$ \\
\hline \multirow[t]{2}{*}{ /cut1 } & -2.164 & -0.876 & -0.932 \\
\hline & $(0.043)$ & $(0.274)$ & $(0.286)$ \\
\hline \multirow[t]{2}{*}{ /cut2 } & -1.682 & -0.390 & -0.446 \\
\hline & $(0.032)$ & $(0.273)$ & $(0.285)$ \\
\hline \multirow[t]{2}{*}{ /cut3 } & -1.042 & 0.266 & 0.210 \\
\hline & $(0.024)$ & $(0.271)$ & $(0.283)$ \\
\hline \multirow[t]{2}{*}{ /cut4 } & -0.553 & 0.766 & 0.712 \\
\hline & $(0.022)$ & $(0.271)$ & $(0.283)$ \\
\hline \multirow[t]{2}{*}{ /cut5 } & 0.227 & 1.100 & 1.047 \\
\hline & $(0.021)$ & $(0.271)$ & $(0.283)$ \\
\hline \multirow[t]{2}{*}{ /cut6 } & 0.275 & 1.616 & 1.563 \\
\hline & $(0.021)$ & $(0.272)$ & $(0.284)$ \\
\hline \multirow[t]{2}{*}{ /cut7 } & 0.745 & 2.103 & 2.052 \\
\hline & $(0.023)$ & $(0.272)$ & $(0.284)$ \\
\hline \multirow[t]{2}{*}{ /cut8 } & 1.354 & 2.725 & 2.676 \\
\hline & $(0.028)$ & $(0.274)$ & $(0.285)$ \\
\hline \multirow[t]{2}{*}{ /cut9 } & 2.038 & 3.413 & 3.368 \\
\hline & $(0.042)$ & $(0.278)$ & $(0.289)$ \\
\hline \multirow[t]{2}{*}{ /cut10 } & 2.588 & 4.006 & 3.965 \\
\hline & $(0.064)$ & $(0.286)$ & $(0.296)$ \\
\hline Region fixed effects & No & No & Yes \\
\hline Pseudo R-squared & 0.003 & 0.008 & 0.009 \\
\hline Number of observations & 6879 & 5733 & 5729 \\
\hline
\end{tabular}

Note: ${ }^{* *},{ }^{* *}$, and ${ }^{*}$ represents significance level at $1 \%, 5 \%$, and $10 \%$ respectively. Standard errors are clustered at household level. The region fixed effects comprises the 16 regions in Germany. 